\title{
Students' Learning Activity Preferences in Korean Tertiary EFL Courses
}

\author{
Michael P. Simon ${ }^{1}$ \\ ${ }^{1}$ Hankuk University of Foreign Studies, Seoul, South Korea \\ Correspondence: Michael P. Simon, Main Building \#335, 107 Imun-ro, Dongdaemun-gu, Seoul 02450, South \\ Korea. E-mail: michael@hufs.ac.kr
}

Received: December 13, 2019

Accepted: January 9, 2020

Online Published: January 15, 2020

doi: 10.20849 /jed.v4i1.700

URL: https://doi.org/10.20849/jed.v4i1.700

\begin{abstract}
The idea of student-centered learning and education has been sweeping through teaching pedagogy for a number of years, with a heavy emphasis in the realm of ESL/EFL. Students have been given the ability to choose topics, and overall classroom atmosphere in the goal of increased student engagement and participation. However, the specific activities students would prefer to engage in have not been researched extensively. The present study examined the learning activity preferences of college students majoring in languages and non-languages in a college EFL classroom in Korea. Students were given a survey which assessed three different parts: their perceived English abilities, their preferences in teacher quality and classroom, and their preferences in activities. The data obtained indicated that students prefer a class which incorporates free-talking as an activity and as an overall methodology. These findings allow teachers to focus specifically on what students would like to practice in a classroom, but also leave a large gap for teachers to fill in terms of how to implement said quality into an entire curriculum.
\end{abstract}

Keywords: student preferences, university students, free-talking, Korean EFL

\section{Introduction}

Over the last few decades of research into second and foreign language development, one of the main findings which has greatly influenced teaching methodology is the notion of learning as a learner-focused, or more widely termed student-centered, activity (Nunan, 1988). Due to this insight, a larger discussion as to the role students have in the classroom beyond mere passive receivers of knowledge has been deliberated by scholars from every corner of the world.

The theory of student-centered education has particularly influenced pedagogy in the EFL/ESL realm in non-Western countries, which has created pedagogical issues where inherit differences in Western-led research literature and cultural norms/beliefs have led teachers to redefine contexts, outcomes, and discussion processes (Frambach, Driessen, Beh, \& Van der Vleuten, 2014). In Korea in particular, the standard concept of a teacher-student relationship in a typical hierarchical structure as well as distinct classroom expectations are still prevalent (Jo, 2018). A suggested way in which to combat this conception has been to make changes within the structure of schools themselves while also changing perceptions of the classroom, beginning with the general population (Thanh, 2010). This is a process which would require an enormous amount of time and effort from every level of the educational establishment in order to obtain desired results.

One of the discovered benefits of the student-centered approach is the role students have in the learning process, which could result in continuing their interest and preference to language learning (Makarova, 1997). A proposed way of getting students to cooperate in the decision-making process is to create a two-way negotiation between teacher and student (Bada \& Okan, 1993; Corder, 1997). In this view, an awareness of the desires and wishes of the students is employed when making decisions on curriculum, classroom activities, and overall atmosphere of a classroom. Horowitz (1987) also warns teachers from ignoring student beliefs about language learning. If the expectations in how a class should be conducted are not met, students' confidence as well as ability to succeed is likely to decline.

Given all the seemingly positive outcomes associated with a student-centered classroom, there remains a larger question as to how much teachers should be yielding to students. It is obvious teachers should not mindlessly 
pander to students, however the appropriate level in which teachers may allow students to make choices in learning activities is still up for debate. The present study, therefore, addresses the following research question:

1) What learning activities do students in communicative EFL courses prefer to engage in?

The overall outcome of this investigation provides a new insight into Korean university students' views on their own language deficiencies and what activities they feel could help improve their English abilities. This research could be particularly informative to teachers and lecturers working in Korea or teacher trainers and lecturers in other content areas within the university system.

\section{Literature Review}

Nunan (1989) has been at the forefront in the call to accommodate learners' needs and preferences from a methodological perspective when designing curriculum. The feelings and emotions of the students are considered of primary importance due to the nature of emotional interaction the students have with language content. It is argued the more students are emotionally involved with the material the more they are able to use and remember it. Thus, when an instructor employs methods and material the students prefer in class, higher achievement can be reached. Arnold (2005) has also been a proponent of a learner-centered curriculum which tends to focus on the affective filter of a student and the emotional impact a lesson has on student achievement. A heavy emphasis on students participating in the decision-making process when it comes to curricular activities and general course content can be felt throughout Arnold's work.

In terms of cognitive processes and learners' abilities to acquire knowledge, student preferences have been researched in a variety of capacities with results shedding new light on how students learn. Reid (1987) distinguished four perceptual learning modalities when surveying students from an assortment of language backgrounds: visual, auditory, kinesthetic, and tactile. Using these four learning modalities as pillars to lesson planning has become a staple in teaching methodology. As much as this has led teachers to create new and dynamic lessons, what seems to be lacking is the incorporation of student-preferred activities which could then be further categorized within the four modalities discovered by Reid. Felder \& Soloman (2000) also categorized learners based on their research regarding dual traits: active vs. reflective, sensing vs. intuitive, visual vs. verbal, and sequential vs. global. However, the major issue regarding categorization and cognitive styles is the overlooking of the student as a whole person (Richards \& Lockhart, 1994). Learners are not entirely privy to one particular style but can be a combination of multiple depending on the circumstances when they are being tested. Thus, it is hard to theorize what kind of activity a student would prefer to engage in based solely on cognitive attributes or traits which could fluctuate depending upon the class setting, style, and emotion of each particular student.

How teachers should conduct classes from the viewpoint of the students themselves is deeply important for overall affective learning. As Barnes \& Lock (2010) have noted in their research on Korean university student perceptions of effective teaching, little is actually known of student preferences in EFL classes and of effective teaching in Korea. Their research dealt exclusively with how students perceived successful teaching and made suggestions as to the implementation of the most popular of those choices in an EFL teacher's classroom. The four main factors instructors should recognize consisted of: (1) the rapport a teacher has with students; (2) the enthusiasm of the instructor; (3) appropriate error correction techniques; and (4) the inclusion of all students in class activities. Learning seems to be enhanced when these four attributes are acknowledged and executed by the language instructor.

Another noted study in the EFL realm in Korea is Park \& Lee's (2006) account of Korean high school students' and teachers' views of effective teaching when broken down into three distinct categories: English proficiency, pedagogical knowledge, and socio-affective skills. The findings illustrated a difference in how teachers perceive the given teaching characteristics with that of the students. Teachers ranked English proficiency the highest in terms of importance while the students ranked pedagogical knowledge the highest. The characteristics which were considered the most important by both teachers and students were reading and speaking proficiency, generating student interest, and building confidence and motivation. Based on their findings, the researchers recommended prospective teachers to be proficient in L2 acquisition theories and methods. Unfortunately, when addressing the discrepancy between the students' beliefs about effective teaching and the teachers', no methodology or applicable suggestion was given.

Other studies investigating the differences in teacher perception of what students need revealed a discrepancy between what students want and what teachers feel students require (Demmon-Berger, 1986; Barkhuizen, 1998; Block, 1994; Koutsoulis, 2003; Lowman, 1995; Witcher et al., 2001). These studies call for a harmony between students and teachers regarding assignments and performance. The researchers do not call for a complete end to 
the teacher-student hierarchy but aim for teachers to create a more balanced approach to content creation. Cray \& Currie (1996) suggest teachers discover the ways in which students learn and to work with their learners in establishing classroom practices. By working with students in creating content it is theorized that enhanced learning can be generated from the dual perspectives of what constitutes an effective language activity.

However, what seems to be lacking in the literature is what specific activities students consider effective in improving their communicative abilities. Mustapha (2010) found that university students studying business proved to have a high level of communicative apprehension when speaking English. When asked for a preferred activity to relieve their anxiety, group discussion was chosen as the main method. And in China, a study was conducted to determine the perceptions of communicative and non-communicative activities in an EFL class (Rao, 2002). The results of the questionnaire indicated that students preferred non-communicative activities more than communicative ones with the researchers theorizing that the relative newness of Communicative Language Teaching in China led to the results. Other such studies evaluating student perceptions of communicative versus non-communicative activities have been undertaken (Green, 1993; İnceçay, 2009) as well as how the dichotomy relates to textbook design (Snider, 2005).

In this study, an investigation as to the preferences students have in communicative activities exclusively was conducted. The research was conducted qualitatively to fully assess student desires in terms of task and activity engagement in English class. The main question the present paper would like to pose is what do students in non-English majors prefer to do when studying English in a communicative classroom? The present paper hopes to fill the void between what teachers feel is necessary and what students actually want in terms of specific activities to increase their English communication proficiency.

\section{The Study}

\subsection{Subjects}

The participants of this study were 43 students (32 females; 11 males) enrolled in a compulsory Freshman-level English communicative class for credit at a university specializing in foreign languages in Seoul, South Korea. None of the participants were majoring in English; however, 24 were majoring in a foreign language while the remaining 19 majored in a non-language. The students ranged from 19-25 years of age with the average being 20 years of age.

\subsection{Instrument}

The data for this study was collected through a 9-item questionnaire administered at the beginning of the second semester (see Appendix for details). The first part of the questionnaire assessed the students' perceptions of their own English abilities to analyze the students' strengths and weaknesses, which was used to add any context to their activity preferences. The item choices in this section were divided into the four language skills plus grammar as this framework for reference in analyzing English skills is the most prevalent in Korean EFL settings (Choi, 2008; Yuasa, 2010). The second part allowed students to specify their preferences in learning English using open-ended questions. To reinforce the students understanding of the items and what was being asked on the questionnaire, both English and Korean were used.

\subsection{Data Analysis}

The data was collected and answers in Korean were translated into English. For the second part of the questionnaire where items regarding student preferences were concerned, answers were transcribed and placed into corresponding categories.

\section{Results}

\subsection{Percieved Strengths and Weaknesses}

A majority of students at $46.5 \%$ believe they are weakest at speaking English as compared to the other parts of language. Grammar was chosen as the second weakest skill at $20.9 \%$ with writing at $11.6 \%$, listening at $13.9 \%$, and reading being the lowest at $6.9 \%$. These results could lead researchers to assume that students in Korea are in need of speaking and grammar activities to counter their perceived weakness, especially for non-language majors whose experience with practicing a language is at a minimum.

The overall percentage of students who feel the most confident was reading at $60.4 \%$ while listening was $25.6 \%$. Speaking was the last chosen at $6.9 \%$. Interestingly, none of the students from any of the majors felt writing was a strength. The possible reason both language majors and non-language majors perceive to have a higher ability to read English is the way English classes are conducted at the primary and secondary school level in Korea. It is very common for students to listen to lectures about grammar and do extensive reading activities for assignments. 
English teachers are also encouraged to use as much English as possible in class, however research has suggested it is still lower than what is expected (Ahn, Baek \& Han, 2004).

\subsection{Preference of Practice}

The results indicate that an overwhelming $74.4 \%$ of students prefer to practice speaking above all other skills. Writing was the next highest at $11.6 \%$, while listening and reading were at $9.3 \%$ and $4.6 \%$ respectively. Even though grammar was chosen as a primary weakness by a large number of students, none of them chose grammar in their preference of practice.

\subsection{Ideal Classroom}

The overall ideal classroom students would like to incorporate was free-talking at $34.8 \%$ with another $23.2 \%$ preferring to collaborate with other students. A classroom with a natural environment was next at $16.2 \%$ with a class incorporating humorous content and presentations at $6.9 \%$. Students also believe the most important quality an English teacher must have is the ability to communicate with students at $25.5 \%$. Interestingly, the next highest quality was to make students participate in class at $13.9 \%$.

\subsection{Motivation to Study}

The primary motivation for most students to study English was the desire to speak well at $34.8 \%$. As well, an overwhelming majority of students do not seem to practice using English outside of a classroom setting (67.4\%). This is not surprising given the limited chances students may be able to use the language in a natural setting.

\subsection{Specific Activity Preference}

Students are very interested in a class which incorporates free-talking into the curriculum (69.8\%). This falls in line with the previous enquiry as to the ideal classroom atmosphere students prefer. Language majors chose free-talking as their activity of choice by $75 \%$ while non-language majors chose it by $63.1 \%$. The remaining options as chosen by students could not be categorized efficiently; for example, debate, talk with teacher, TV show, and cultural contents.

\section{Discussion}

First, the data indicates students' speaking ability is perceived the weakest skill, and thusly, students feel it should be focused on in an EFL classroom. This could be due to the fact that for most of a Korean students' education in English, grammar and reading are the primary focuses, in large part to prepare students for the university entrance exam. Kim (1987) found that Korean students had trouble in speaking English due to the poor and inexperienced planning of teachers who themselves did not speak English well. As indicated in the present findings, speaking English is not generally practiced outside of the classroom which leaves the EFL class as the only option to practice speaking. Students indicated their motivation to study English was a general desire to speak better, leaving a very large pedological gap for teachers to fill.

Second, students are more scattered in their opinions on what makes a good teacher. Many students point to communication with students, but when broken down between language majors and non-language majors, it is harder to find a definitive quality that most students feel make an effective teacher. This coincides with Barnes and Lock's (2010) finding in which 40 attributes were discovered for effective EFL lectures. Asking an instructor to attempt to adhere to all 40 of those attributes or even to the ones discovered in this research is a tall order to ask a teacher. However, it is suggested teachers take a harder look at the results from this and other research to reform how they approach and interact with students in a classroom. Being consciously aware of how teachers are perceived by their students influences the approach teachers take in the classroom, which then influences student engagement and participation.

The third and most important finding of this investigation was the students' attitude to free-talking as an activity and as a feature of an ideal classroom atmosphere. Non-language majors were more various in their choices of an ideal classroom, but the majority still believed being able to talk freely was an idyllic way to handle class. In the students' choice of preferred activity, the majority of both language majors and non-language majors chose free-talking as their preferred method. If students desire free-talking as the primary way in which to learn English, it is evident that more research is needed to shed light on this seemingly sparsely investigated topic. Kim and Dirks (2011) have seen the benefits of free-talking in an EFL classroom and their research has suggested new methods of making free-talking more beneficial lexically while also giving students more confidence in their speaking. However, Kim (2011) also found discrepancies between what Korean students found to be free-talking and what the professors deemed appropriate free-talking. Other than Kim's research there are no other investigations to the incorporation of free-talking into EFL classrooms in Korea. 
What instructors must now decide is how to marry what they feel students need to succeed in a language and what the students themselves feel is the most beneficial way for them to learn a language. As mentioned in the research by Bada \& Okan (1993) and Corder, (1997), the only way to satisfy both parties is a genuine negotiation of content. In this regard it seems evident instructors in Korea should consider integrating free-talking and other speaking activities into their curricula in order to mollify the desires of the students.

\section{Conclusion}

Creating curricula to meet the needs of the given institution as well as being sensitive to the students' own needs is a task which continues to plague teachers at every educational level. In this study, an investigation as to the preferences students have in teacher personality, classroom atmosphere, and activities was undertaken to assess the validity of allowing students to assist teachers in selecting curricular content. The other aspect of the present research was to address the issue of student preference from students with different majors. In part, the general consensus of most students was to practice speaking, which seems achievable for teachers of all backgrounds to seriously consider adjusting curriculum to include speaking activities like free-talking.

With these results comes the caveat of making sure instructors know what their students prefer in an EFL classroom. Using results such as these to stereotype student requests from all majors and backgrounds denies the students a chance to fully develop their desires. It is suggested that instructors take the time and effort to pose questions based on this research to their students in order to gain a larger insight into what their students would like to see in an English class. If teachers were required to assess their students' preferences at the beginning of a semester, it could then give the teacher a chance to cooperate with the students in terms of content and activity selection to be used in the course.

The main limitation to this research is the place in which it was conducted. As the subjects were enrolled in a foreign language university it could have been an influence in how they perceive language activities given the general environment. A study such as this should be conducted in regular university settings to fully assess the ideas and desires of normal students without the possible influence that the university system or current course offerings provides. The second limitation to this research was the relatively low number of student participants. A larger number of subjects would have enriched and made the results more prevalent. Additional research in this vein should attempt to collect more subjects from diverse educational backgrounds to complete the bigger question of what students prefer to do in EFL courses.

\section{References}

Arnold, J. (2005). Affect in language learning. Cambridge, U.K.: Cambridge University Press.

Bada, E., \& Okan, Z. (2000). Students' language learning preferences. TESL-EJ, 4(3), 1-15.

Barkhuizen, G. P. (1998). Discovering learners' perceptions of ESL classroom teaching/learning activities in a South African context. TESOL Quarterly, 32, 85-108. https://doi.org/10.2307/3587903

Barnes, B. D., \& Lock, G. (2010) The Attributes of Effective Lectures of English as a Foreign Language as Perceived by Students in a Korean University. Australian Journal of Teacher Education, 35(1), 139-152. https://doi.org/10.14221/ajte.2010v35n1.2

Block, D. (1994). A day in the life of a class: Teacher/learner perceptions of task purpose in conflict. System, 22, 473-486. https://doi.org/10.1016/0346-251X(94)90004-3

Choi, I. C. (2008). The impact of EFL testing on EFL education in Korea. Language Testing, 25(1), 39-62. https://doi.org/10.1177/0265532207083744

Corder, S. (1997). Language teaching and learning: a social encounter. In Y. Brown, \& Crymes (Eds.), On TESOL (p. 77). Washington, DC.: TESOL.

Cray, E., \& Currie, P. (1996). Linking adult learners with the education of L2 teachers. TESOL Quarterly, 30(1), 113-130. https://doi.org/10.2307/3587609

Demmon-Berger, D. (1986). Effective teaching: Observations from research. Arlington, VA: American Association of School Administrators (ERIC Eric Document Reproduction Service No. 274 087).

Eslami-Rasekh, Z., \& Valizadeh, K. (2004). Classroom Activities Viewed from Different Perspectives: Learners' Voice and Teachers' Voice. TESL-EJ, 8(3), n3.

Felder, R. M., \& Soloman, B. A. (2000). Learning styles and strategies. Retrieved April 11, 2019, from http://studenthublive.open.ac.uk/sites/studenthublive.open.ac.uk/files/Felder\%20Learning\%20Styles\%20an d\%20Strategies.pdf 
Frambach, J. M., Driessen, E. W., Beh, P., \& Van der Vleuten, C. P. (2014). Quiet or questioning? Students' discussion behaviors in student-centered education across cultures. Studies in Higher Education, 39(6), 1001-1021. https://doi.org/10.1080/03075079.2012.754865

Green, J. (1993). Student Attitudes toward Communicative and Non-Communicative Activities: Do Enjoyment and Effectiveness Go Together?. The Modern Language Journal, 77(1), 1-10. https://doi.org/10.1111/j.1540-4781.1993.tb01938.x

Horowitz, E. K. (1987). Surveying student beliefs about language learning. In A. Wenden, \& J. Rubin (Eds.), Learner strategies in language learning (pp. 119-129). Edgewood Cliffs, NY: Prentice-Hall.

İnceçay, G., \& İnceçay, V. (2009). Turkish university students' perceptions of communicative and non-communicative activities in EFL classroom. Procedia-Social and Behavioral Sciences, 1(1), 618-622. https://doi.org/10.1016/j.sbspro.2009.01.110

Jo, J. M. (2018). The challenges teachers and students face when student-centered policy was incorporated in the classrooms. The Journal of Learner-Centered Curriculum and Instruction, 18(15), 383-403. https://doi.org/10.22251/jlcci.2018.18.15.383

Kim, B. W. (1987). Why Koreans Study English But Don't Speak It Well. English Teaching, 34, 63-86.

Kim, N. B. (2011). Korean students' perceptions of free-talking and international professors' role recognition. English Language \& Literature Teaching, 17(3), 119-139.

Kim, N. B., \& Dirks, B. (2011). Effective free-talking methods in a Korean university setting. Modern English Education, 12(4), 192-214.

Koutsoulis, M. (2003). The characteristics of the effective teacher in Cyprus public high school: The students' perspective. Arlington, VA: American Association of School Administrators (ERIC Eric Document Reproduction Service No. 478 761).

Liu, D., Ahn, G. S., Baek, K. S., \& Han, N. O. (2004). South Korean high school English teachers' code switching: Questions and challenges in the drive for maximal use of English in teaching. TESOL Quarterly, 38(4), 605-638. https://doi.org/10.2307/3588282

Lowman, J. (1996). Characteristics of exemplary teachers. New Directions for Teaching and Learning, 65, 33-40. https://doi.org/10.1002/t1.37219966508

Makarova, V. (1997). Discovering phonetics. The Language Teacher Online, 21(3). Japan: TLT Online Editor. Retrieved April 10, 2019, from http://langue.hyper.chubu.ac.jp/jalt/pub/lt1/97/mar/phonetic.html

Mustapha, W. Z. W. (2010). ESL students communication apprehension and their choice of communicative activities. Asean Journal of Teaching and Learning in Higher Education (AJTLHE), 2(1), 22-29.

Nunan, D. (1988). The learner-centered curriculum. Cambridge, UK: Cambridge University Press. https://doi.org/10.1017/CBO9781139524506

Nunan, D. (1989). Hidden agendas: The role of the learner in programme implementation. In R. K. Johnson (Ed.), The Second Language Curriculum. Cambridge, UK: Cambridge University Press. https://doi.org/10.1017/CBO9781139524520.013

Park, G. P., \& Lee, H. W. (2006). The characteristics of effective English teachers as perceived by high school teachers and students in Korea. Asia Pacific Education Review, 7(2), 236-248. https://doi.org/10.1007/BF03031547

Rao, Z. (2002). Chinese students' perceptions of communicative and non-communicative activities in EFLclassroom. System, 30, 85-105. https://doi.org/10.1016/S0346-251X(01)00050-1

Reid, J. (1987). The learning style preferences of ESL students. TESOL Quarterly, 21, 87-103. https://doi.org/10.2307/3586356

Richards, J., \& Lockhart, C. (1994). Reflective Teaching in Second Language Classrooms. Cambridge, UK: Cambridge University Press. https://doi.org/10.1017/CBO9780511667169

Snider, D. (2005). Communicative and Non-Communicative Activities in First-Year College German Textbooks. Die Unterrichtspraxis/Teaching German, 163-171. https://doi.org/10.1111/j.1756-1221.2005.tb00054.x

Spratt, M. (1999). How good are we at knowing what learners like? System, 27, 141-155. https://doi.org/10.1016/S0346-251X(99)00013-5 
Thanh, P. T. H. (2010). Implementing a student-centered learning approach at Vietnamese higher education institutions: barriers under. Journal of Futures Studies, 15(1), 21-38.

Warden, C., \& Lin, A. (2019). Different attitudes among non-English major EFL students. The Internet TESL Journal, 2(7). Retrieved April 10, 2019, from http://www.iteslj.org

Witcher, A., Onwuegbuzie, A., \& Minor, L. (2001). Characteristics of effective teachers: Perceptions of preservice teachers. Research in the Schools, 8, 45-57.

Yuasa, K. (2010). English Textbooks in Japan and Korea. Journal of Pan-Pacific Association of Applied Linguistics, 14(1), 147-158.

\section{Appendix}

1) What part of English would you like to practice? 영어를 공부하실 때 다음 분야에서 어느 것을 더 공부하기를 원하십니까?

_ Speaking __ Listening __ Reading __ Grammar _ Writing

2) What are you weakest at? 당신의 취약부분은 어느 것입니까?

Speaking __ Listening __ Reading __ Grammar__Writing

3) What are you strongest at? 당신의 강한부분은 어느 것입니까?

Speaking __ Listening __ Reading __ Grammar__ Writing

4) What does your ideal classroom look like? 당신이 원하는 또는 선호하는 강의방법이나 강의환경은 무엇입니까?

5) What is the most important quality of an English teacher? 영어선생님의 가장 중요한 점은 무엇이라고 생각합니까?

6) What is your motivation to study English? 영어공부를 하는 당신의 동기는 무엇입니까?

7) Do you practice English outside of the classroom? 학업외 영어연습을 하십니까?

8) What would you like to learn about in English class? 영어시간에 어떤 것들을 배우고 싶습니까?

9) What kind of activities do you want to do in English class? 영어시간에 어떤 방법으로 영어를 배우고 싶습니까?

\section{Copyrights}

Copyright for this article is retained by the author(s), with first publication rights granted to the journal.

This is an open-access article distributed under the terms and conditions of the Creative Commons Attribution license (http://creativecommons.org/licenses/by/4.0/). 